\title{
Several rare freshwater planktic Cyanobacteria (Cyanoprokaryotes) from reservoirs in South America
}

\author{
Jiøi Komárek ${ }^{1,2,4}$ and Jaroslava Komárková-Legnerováa 2,3
}

Received: 26.07.2005; accepted: 28.11.2006

\begin{abstract}
Several rare freshwater planktic cyanobacteria (cyanoprokaryotes) from reservoirs in South America). Ten rare filamentous cyanobacterial oscillatorialean morphospecies, recorded in plankton of freshwater water bodies in tropical and subtropical South America, mainly in São Paulo State, Brazil, are described in this article. Four morphospecies from the genera Romeria, Arthrospira, Planktothricoides and Hormoscilla are not identifiable according to literature, and they are described as new for science.
\end{abstract}

Key words: Cyanobacteria, new species, phytoplankton, taxonomy

RESUMO - (Cianobactérias (Cianoprokaryotes) raras em reservatórios da América do Sul). Dez morfoespécies de cianobactérias filamentosas oscillarioides, registrados no plâncton de reservatórios tropicais e subtropicais da América do Sul, principalmente no Estado de São Paulo, Brasil, são descritos no presente artigo. Quatro morfoespécies, classificados nos gêneros Romeria, Arthrospira, Planktothricoides e Hormoscilla não são identificáveis de acordo com a literatura e são propostos como novos para a ciência.

Palavras-chave: Cianobactéria, espécies novas, fitoplâncton, taxonomia

\section{Introduction}

From 1991 to 1996, we have participated in the investigation of the freshwater planktic cyanobacteria from eutrophic water reservoirs of São Paulo State, southeastern (SE) Brazil. For comparison, we studied several other samples from different South-American freshwater reservoirs. Results concerning the chroococcal cyanobacterial species were published in previous studies (Azevedo et al. 2003, Sant'Anna et al. 2004, Senna et al. 1998). Several simple filamentous, non-heterocytous (oscillatorialean) species definable according to traditional cytomorphological and ecological criteria were found in these samples, but they could not be identified according to known cyanoprokaryotic diversity. Ten morphotypes, which correspond to traditional cyanobacterial species recognizable in nature, but rarely occurring and not yet satisfactory known and described, are mentioned in this article, among which four are new for science.

\section{Material and methods}

The samples were collected occasionally from 1991 to 1996 by plankton-net (10 and $20 \mu \mathrm{m})$ or as free water-samples $(0.5 \mathrm{~L})$ from the subsurface layer of different water bodies (reservoirs, lakes and rivers), in various localities of southeastern Brazil, especially in São Paulo State. One new species, found in samples from Peru, is also included. All samples were preserved in 2-3\% formaldehyde solution, and the water samples were concentrated by sedimentation. The optical microscopy was used for recognition of phenotypic characters, combined with staining procedures (by lugol, methylen blue and China-ink) and using the magnification up to $1000 \times$. Descriptions of species concern to our samples from Brazilian (and one Peruvian) localities. The new descriptions were applied in the cases when the morphological status of developed populations did not correspond to any status of any known species. Only selected localities, in which the corresponding species were registered in

1. Institute of Botany, Czech Academy of Sciences, Dukelska, 135, 37982 Trěboň, Czech Republic

2. University of South Bohemia, Faculty of Biology, Èeské Budějovice, Czech Republic

3. Czech Academy of Sciences, Institute of Hydrobiology, Èeské Budějovice, Czech Republic

4. Corresponding author: komarek@butbn.cas.cz 
typical state, are cited after descriptions.

The nomenclatoric principles for cyanoprokaryotes (cyanobacteria) are intensely discussed at present (Hoffmann 2005). The typification practice is particularly confused, because the both, botanical and bacteriological codes (and especially the rules for typification) are officially used and applied differently by various authors.

\section{Results and Discussion}

\section{Romeria sp.}

Figure 1

Solitary cells up to short filaments (usually 3-celled, maximally 8-celled), almost straight to slightly arcuated or irregularly flexuous with cylindrical cells, constricted at cross walls; cells arcuated or slightly sigmoid, rounded at ends, of uneven length in one and the same trichome, $2.6-8 \times 0.8-1.2(-1.5) \mu \mathrm{m}$, pale bluegreen, without aerotopes.

Studied material: BRASIL. São PAuLo: São Paulo, lake in "Clube da Penha", 2-VI-1999, C.L. Sant'Anna s.n. (SP336724).

Common species in plankton of eutrophic reservoirs, where it grows epigloeic on the diffluent slimy surface of colonies of green tetrasporal and coccoid algae, rarely also on the surface of the mucilage of Microcystis aeruginosa (Kütz.) Kütz. Typical populations were collected in Broa and Barra Bonita reservoirs, and in lake of Clube da Penha, in São Paulo State. This morphotype occurs in nature usually in 3 to 8 celled filamentous formation with typical Romeria structure, therefore, it was preliminary designated in the review of the genus Romeria (Komárek 2001) as a separate species "Romeria heterocellularis". The relations with the genus Synechococcus are not clear (similar involution formations occur in Synechococcus in culture under rather stress conditions); however, our populations were studied only from nature and they always appeared in the same morphological state, not corresponding to any known Romeria or Synechococcus species. However, both these genera are very variable, and we are not sure, whether it deals really about a special genotype or only a modification of some other species.

Romeria hieroglyphica Kom. \& Kom.-Legn., sp. nov. TYPE: BRASIL. São PAULO: São Carlos, pool near Broa Reservoir, 2-VII-1996, J. Komárek s.n. (holotype SP355744).

Filamenta libere natantia, longa, intense irregulariter flexuosa, multicellularia, ad dissepimenta clare constricta. Vagina carens, sed involucrum mucilaginosum, indistinctum, achromaticum, homogeneum, tenuis (plus minusve 3-4 um latum), ad marginem diffluens, circum filamenta adest. Cellulae cylindricae, longae, leve curvatae vel sigmoideae, 4.5-9 um longae, 1-1.3 $\mu$ m latae, contentu pallide aeruginoso, homogeneo; cellula apicalis cylindrica et rotundata, similar ad cellulis intercalaribus. Reproductio: fragmentatione filamentorum, cellulae perpendiculariter dividuntur. Habitatio: Planktice in piscinis eutrophicis parvis; locus classicus: stagnum inter oppida São Carlos et Broa, Brasilia orientale-meridionalis (provincia São Paulo).

Figure 2

Filaments long, intensely and irregularly flexuous, multicellular, composed by cylindrical cells, distinctly constricted at cross walls, with indistict, narrow ( $\pm 3-4 \mu \mathrm{m}$ wide), colorless, thin, mucilaginous envelope, diffuse at the margin; cells slightly curved or sigmoidal, always longer than wide, $4.5-9 \times 1-1.3 \mu \mathrm{m}$, pale grayish-blue, with homogeneous content; apical cells cylindrical and rounded, morphologically identical to intercalar cells.

Free-living, planktic species in small, heavy eutrophic water reservoirs, particularly in pastures of cattle, in the vicinity of São Carlos (SP). The typical specimens were described according to population collected from plankton of a small shallow pond on pastures near the road from São Carlos and Broa Reservoir.

Pseudanabaena voronichinii Anag., Preslia 73: 360. 2001.

Figure 3

Short filaments, usually 2-3-celled, maximally 6(-8)-celled, straight or slightly arcuated, composed from cells always distinctly longer than wide, distinctly constricted at cross-walls, without individual sheaths; irregularly distributed in the peripheral parts of slimy colonies of Microcystis protocystis Crow and M. aeruginosa; cells cylindrical, with pale blue-green content, visible peripheral chromatoplasmic region, in the central part with fine granulation (immersion!), 3.2$8(-9.4) \times(1.4-) 1.6-1.8 \mu \mathrm{m}$; apical cells obtusely conical to pointed. 
Studied material: BRASIL. São PAULO: São Paulo, lake in Botanical Garden, 27-IX-1996, J. Komárek s.n. (SP355963), lake in Zoological Garden, 26-VI-1995, C.L. Sant'Anna s.n. (SP355962).

Pseudanabaena voronichinii is considered as uncommon species, but with more or less a cosmopolitan distribution. From the widely distributed, ecologically and morphologically similar P. mucicola (Hub.-Pest. \& Naumann) Schwabe it differs mainly by the distinctly longer cells. In Brazil, it was found for the first time and occurred in mucilage of Microcystis protocystis, sometimes also in $M$. aeruginosa (Brazilian type), but it was always absent inside the colonies of M. panniformis Kom. et al., also when it was present in the same planktic community and in the same sample. However, according to experiences with $P$. mucicola, this situation could be different in various reservoirs. We have found this species especially in the whole cascade of lakes in Zoological and Botanical gardens in São Paulo in 1996.

Planktolyngbya cf. minor (Geitler) Kom. \& Cronberg, Nova Hedwigia 73: 142. 2001. Lyngbya limnetica f. minor Geitler \& Ruttner, Oster. Bot. Z. 84(4): 287-291. 1935.

Figure 4

Filaments solitary, planktic, very straight, with very fine and thin, colorless, transparent, but distinct sheaths, 0.9-1.4 $\mu \mathrm{m}$ wide. Trichomes pale grayish-blue-green, not constricted at hardly visible cross-walls (in optical microscope); cells short, slightly longer than wide, terminal cells rounded.

Studied material: BRASIL. São PAULO: Cachoeira Reservoir, 13-IX-1996, C.L. Sant'Anna s.n. (SP355964).

Evidently this is a pantropical and subtropical morphospecies, originally described from southeastern Asia (Indonesia), later found in many localities in Africa and tropical America, but also sporadically recorded from the Mediterranean region in Europe. It differs only slightly by dimensions (narrower filaments) from the similar and commonly distributed Planktolyngbya limnetica (Lemm.) Kom.-Legn. \& Cronberg, but $P$. minor (Gleitler) Kom. \& Cronberg occurs as a special and clearly recognizable morphotype only in the plankton of usually large tropical freshwater reservoirs. It is little known from South America, in the State of São Paulo was found the morphotype little wider than typical $P$. minor (in original diagnosis the cells are up to $5.6 \mu \mathrm{m}$ long and $0.6-0.8 \mu \mathrm{m}$ wide), but habitually very similar to the type. It was collected also in large reservoirs (Atibainha, Cachoeira and Guarapiranga), and in small water bodies near Ubatuba, SP.

Geitlerinema unigranulatum (Singh) Kom. \& Azevedo, Algol. Stud. 99: 51. 2000. Oscillatoria punctata var. unigranulata Singh, Proc. Indian Acad. Sci. B. (9): 68. 1939.

Figure 5

Trichomes occur solitary in plankton, thin, without sheaths (Unsheathed filaments), pale gray-bluish or yellowish-green, not constricted at cross-walls, \pm straight when short, longer slightly flexuous, up to very long and irregularly waved, (1-)1.3-1.9(-2) $\mu \mathrm{m}$ wide. Cells always longer than wide, (4.2-)6.2-9.2 $\mu \mathrm{m}$ long, with solitary small granules at indistinct crosswalls, without aerotopes; granules sometimes lacking; apical cells cylindrical, not attenuated, rounded or obtuse at the end. All cells are capable to divide, including the terminal ones.

Studied material: BRASIL. São PAulo: São Paulo, Garças Lake, 15-I-1997, C.L. Sant'Anna s.n. (SP365577).

This species was recently studied and the original description was revised, particularly from Brazilian localities. It is probably a pantropical morphospecies, evidently common in reservoirs of southeastern Brazil. We have studied further populations from numerous localities other than those cited in the original paper by Komárek \& Azevedo (2000), and we should like to stress the morphological uniformity of this filamentous cyanobacterium in planktic environment, and its common occurrence in the State of São Paulo.

Arthrospira santannae Kom. \& Kom.-Legn., sp. nov. TYPE: BRASIL. RIO DE JANEIRO: Rio de Janeiro, ponds, 13-IX-1996, C.L. Sant'Anna s.n. (holotype SP355964).

Trichoma libere natantia, solitaria, sine vaginis vel involucris mucilaginosis distinctis, dense vel libere dextrorse et plus minusve regulariter helicoidales, cylindrical, ad apices not attenuate, ad dissepimenta not constricta, 2.8-3.8 $\mu \mathrm{m}$ lata; spirae longitudine equaliter, (8.8)-12.5-18.5 $\mu \mathrm{m}$ latae, 5.5-5.8 $\mu \mathrm{m}$ altae (sed ad $40 \mathrm{~mm}$ in trichomatibus libere torsis); dissepimenta tenua, paucim visibilia in microscopis opticis. Cellulae 1- 


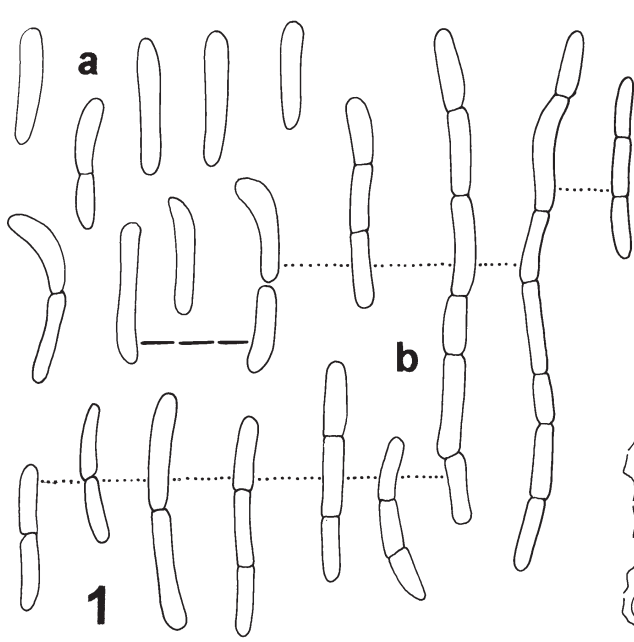

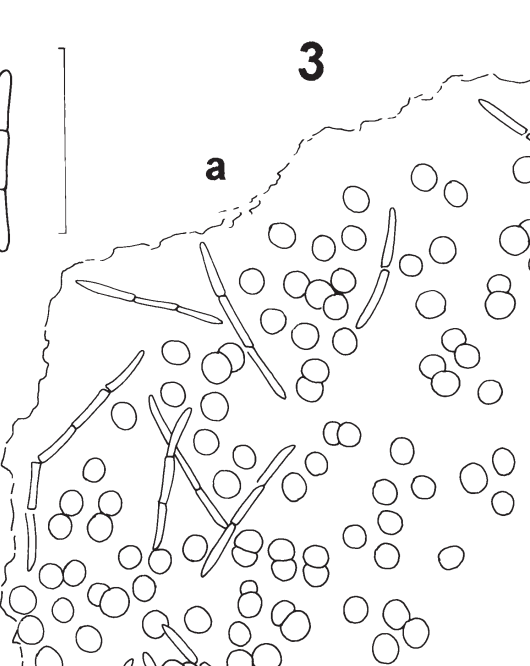

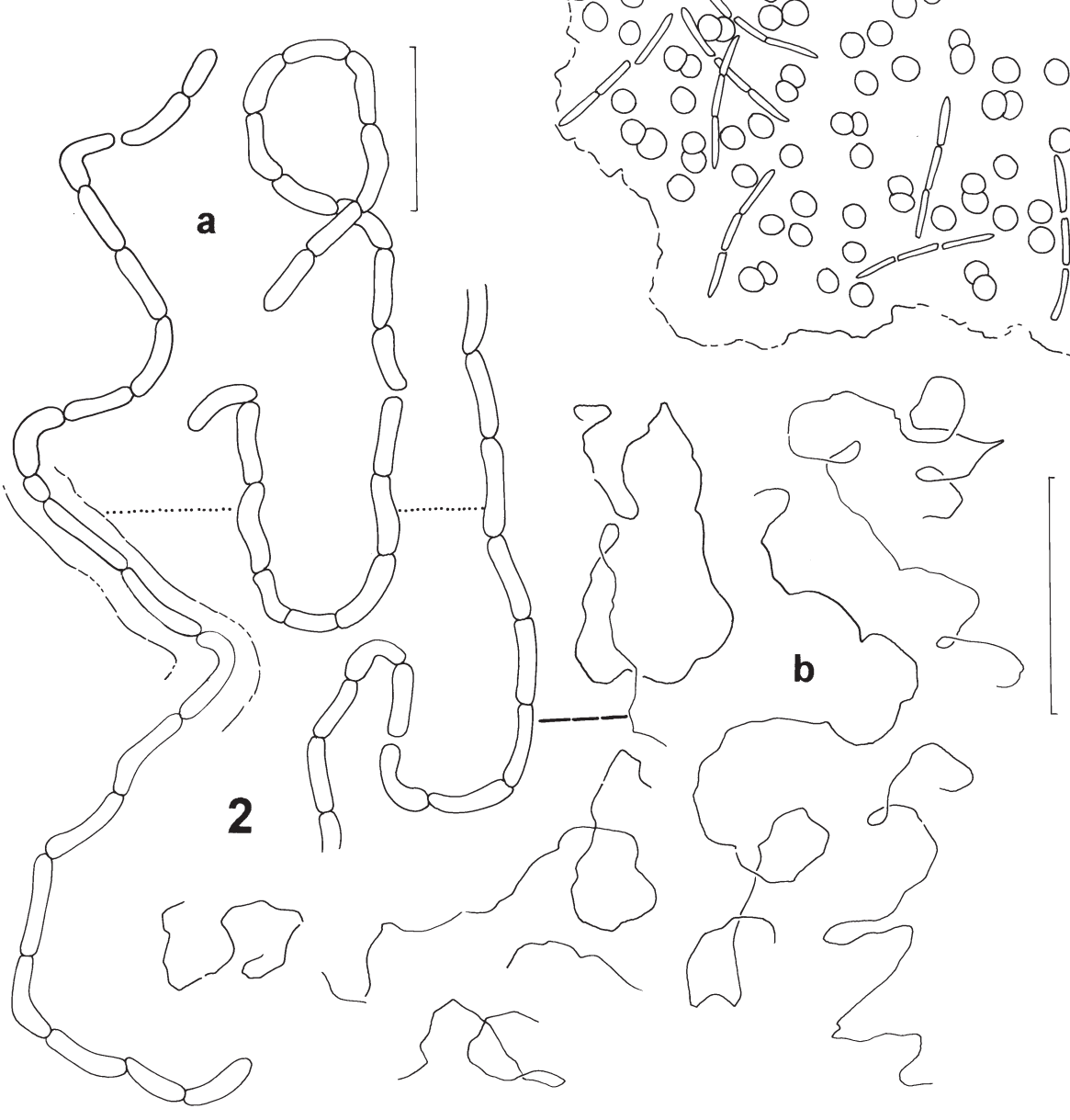

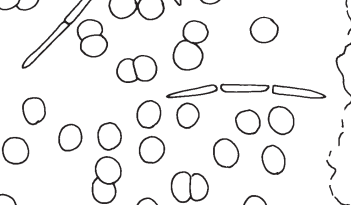
$8 \quad 8000$

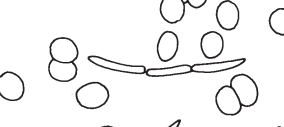

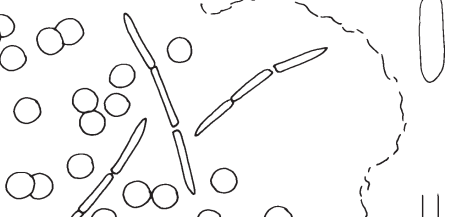<smiles>C1CCC1</smiles> 


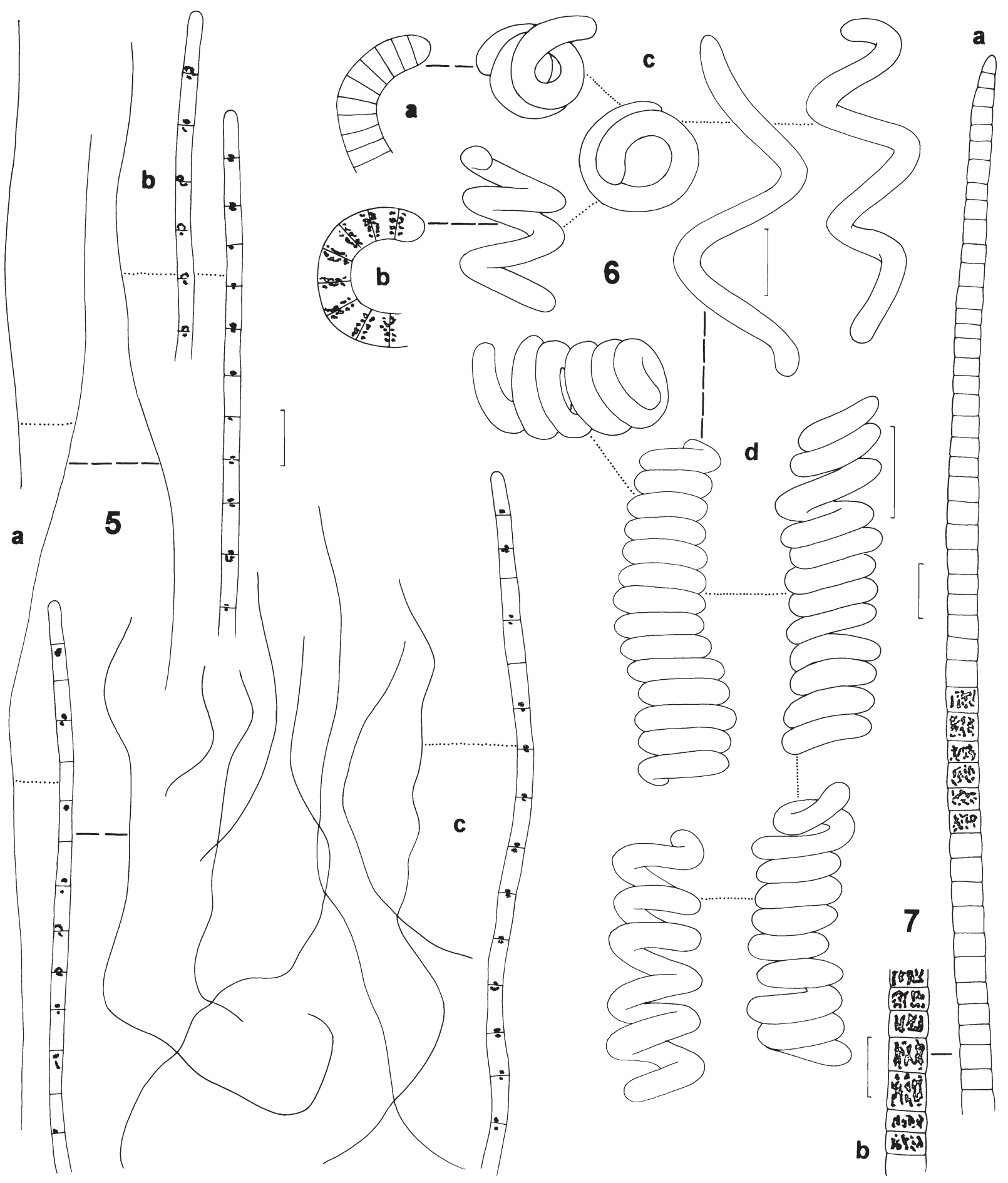

Figure 5. Geitlerinema unigranulatum: a-c. Form of trichomes and details of trichomes from different localities. Figure 6. Arthronema dantannae: a-b. Ends of trichomes with visible cells; c-d. Variability in coiled of trichomes. Figure 7. Planktothricoides attenuata: a. Terminal part of a trichome; b. Detail of cells with aerotopes. All figures original; all bars $=10 \mu \mathrm{m}$. 
$4 \times 2.8-3.8 \mu \mathrm{m}$, contentu pallide aeruginoso, interdum cum granulis parvis ad dissepimenta locatis, cum vesiculis gaseosis facultativis; cellula terminalis rotundata, sine calyptra. Heterocytae akinetesque carentes. Habitatio: Planktice in piscinis prope oppido Rio de Janeiro, Brasília orientale-meridionalis (província Rio de Janeiro). Figure 6

Filaments (trichomes) solitary, free-floating, without sheaths, screw-like, densely or loosely righthanded (dextral) coiled, cylindrical along the whole length, not attenuated or tapered at the ends, not constricted at cross-walls; the width of coiling is the same along the whole trichome (not narrowed towards ends); trichome width $2.8-3.8 \mu \mathrm{m}$, width of coils (8.8-)12.5-18.2(-18.5) $\mu \mathrm{m}$, height of coils (very variable) 5.5-5.8 (in densely coiled trichomes) up to 25-40 $\mu \mathrm{m}$ (loosely coiled trichomes). Cross-walls hardly visible (staining !), cells pale blue-green, \pm isodiametric or shorter than wide after division (up to $1 / 3$ of width), sometimes slightly granular at crosswalls, aerotopes not observed, but possibly gas vesicles are present; terminal cells widely rounded, without calyptra.

Characteristic species, evidently belonging to the genus Arthrospira in spite of the relatively small dimensions and often hardly visible cross-walls (staining, immersion !). The coiling is usually tight, but with numerous irregularities and freely coiled sections.

Planktothricoides attenuata Kom. \& Kom.-Legn., sp. nov. TYPE: PERU. Amazonas: Iquitos, Cucho Aguajal, 4-IV-1981, H. Fernando s.n. (holotype WAT5.1)

Trichoma libere natantia, solitaria, sine vaginis, recta vel paucim arcuata, ad dissepimenta not vel paucim constricta, plus minusve cylindrica et ad apices usu gradatim attenuata, ad 6-6.8 $\mu \mathrm{m}$ lata in media parte, apice ad 3.5-4 $\mu$ m lata. Cellulae plus minusve isodiametricae vel paucim abbreviatae, contentu pallide aeruginoso vel olivaceo-viridi, interdum cum aerotopis numerosis parvis facultativis; cellula apicalis conicerotundata vel rotundata, sine calyptra. Heterocytae akinetesque carentes. Habitatio: Planktice metaphyticeque in piscinis stagnisque tropicalibus, not contaminatis, praecipue cum plantis aquaticis numerosis; locus classicus: stagnum sine nomine in regione cum sylvis tropicis humidis, Peruvia orientale-septentrionalis, prope oppido Iquitos
(Cucho Aguajal, Amazonas).

Figure 7

Trichomes solitary, free-floating and metaphytic in littoral of tropical natural lakes, straight, 6-6.8 $\mu \mathrm{m}$ wide in the middle, very gradually tapered towards ends, at the end 3.5-4 $\mu$ m wide (on well developed trichomes), not constricted or indistinctly constricted at cross-walls (immersion !), in terminal parts sometimes slightly curved; cells \pm isodiametric or slightly shorter after division, pale blue-green or olivegreen, facultative with numerous, small aerotopes (sometimes segments of trichomes without aerotopes were observed), apical cells conical-rounded or rounded, without calyptra.

It is morphologically distinct species, which was found in samples from reservoirs in the Amazon Basin (in Peru and Brazil). It corresponds by cytology and morphology mostly to the Planktothricoides raciborskii (Woloszynska) Suda \& M.M. Watanabe, which was separated recently from the genus Planktothrix into a special genus Planktothricoides by Suda et al. (2002). We describe, therefore, this special morphospecies, known up to now only from tropical regions of South America, as a member of this new genus. This classification should be confirmed, of course, by molecular evaluation.

Trichodesmium cf. lacustre Klebahn, Flora 80: 271. 1895.

Figure 8

Trichomes free-floating, rarely solitary, usually \pm parallel agglomerated in microscopic fascicles with several trichomes, distinctly constricted at cross walls, cylindrical, sometimes narrowed at the ends, or terminated by 1 to $3 \pm$ spherical up to elongated, cylindrical and more narrowed, or, on the contrary, widened cells with light, up to hyaline content; trichomes 5.4-6.4 $\mu \mathrm{m}$ wide, widened terminal cells up to $7.6 \mu \mathrm{m}$ wide; trichomes in fascicles motile, creeping, changing position. Cells slightly barrel-shaped with densely arranged aerotopes, \pm isodiametric or slightly shorter or longer than wide, end cells (narrowed and elongated) often without aerotopes, widened terminal cells with aerotopes.

Studied material: BRASIL. São PAULO: Ubatuba, shallow coastal lake, 2-X-1996, J. Komárek s.n. (SP365598).

Little known and uncommon cyanoprokaryotic morphospecies, occurring sporadically and very 
dispersed in northern Europe (Denmark, Latvia, Poland, Sweden) and tropical regions in S and E Asia (Burma, China, India, Japan), possibly also in the USA. In Brazil, a not very rich population was found in an atypical locality, in the plankton of a small, shallow lake with submerged vegetation and slightly salty (brackish) water near Ubatuba. The identity of all up to now described populations over the world (including the Brazilian ones) should be revised.

Hormoscilla fragmentosa Kom. \& Kom.-Legn., sp. nov. TYPE: BRASIL. São Paulo: Botucatu, Capivara river, 2-X-1990, H.T. Oliveira s.n. (holotype SP365599).

Trichoma solitaria vel paucim fasciculata, curta, recta vel paucim arcuata, fragmentosa, sine vaginis, cum mucilago indistincto, fino, homogeneo, achromatico, ad marginem diffluente, cylindrica, ad apices not attenuata, ad dissepimenta distincte constricta, 6-6.6 $\mu$ m lata; fragmentatio ad cellula solitaria. Cellulae breve barriliformes, semper distincte brevior quam latae, contentu pallide aeruginoso vel virescente, cum granulis solitariis, parvis; cellula terminalis rotundata, interdum angustior quam cellulae intercalares. Reproductio fragmentatione trichomatibus. Heterocytae akinetesque carentes. Habitatio: Planktice, metaphytice vel periphytice in stagnis vel aquis fluentibus; locus classicus: in flumine Capivara prope oppido Botucatu, Brasilia orientale-meridionalis (provincia São Paulo).

Figure 9

Trichomes agglomerated into irregular clusters, short, straight or very slighly arcuated, cylindrical, not tapered towards ends, distinctly constricted at cross walls, easily fragmenting in short few-celled segments, up to unicells, 6-6.6 $\mu \mathrm{m}$ wide. Cells shortly barrelshaped, always distinctly shorter than wide, with pale blue-green or greenish content, with small, solitary granules; end cells widely rounded, sometimes slightly narrower than other cells. Reproduction by fragmentation of trichomes.

The genus Hormoscilla is characterized by short, straight trichomes, which easily fragmentate into short, usually immotile segments (Anagnostidis \& Komárek 1988). From the similar genus Borzia, it differs by short cells and oscillatoriacean structure of cells. This little known genus has about 6-7 rare morphospecies. $H$. fragmentosa differs from the other species of Hormoscilla by morphology of cells and trichomes (very straight trichomes, and by ecology).

Lyngbya robusta (Parakutty) comb. nov. Lyngbya hieronymusii f. robusta Parakutty, Proc. Ind. Acad. Sci., 11: 123. 1940.

Figure 10

Filaments free-floating in plankton of large freshwater reservoirs, solitary, \pm straight or slightly arcuated, 17-28 $\mu \mathrm{m}$ wide; sheaths \pm thick, firm, colorless, smooth on the surface, cylindrical; trichomes cylindrical, not or indistinctly constricted at crosswalls, cells 14.5-19(-21) $\mu \mathrm{m}$ wide, short, only 2.6-5.1 $\mu \mathrm{m}$ long, with numerous aerotopes in cells; apical cells widely rounded.

Studied material: BRASIL. São PaUlo: Cantareira system, Paiva Castro Reservoir, 10-XI-1996, C.L. Sant'Anna s.n. (SP355892).

Typical L. hieronymusii and its "f. robusta" belong to a few planktic Lyngbya species living in solitary trichomes and containing numerous aerotopes (clusters of gas vesicles) in cells. This planktic type of Lyngbya species represents probably a special cluster of Lyngbya morphospecies, related to other planktic, aerotopated oscillatorialean cyanobacteria (compare Suda et al. 1998, 2002). The typical L. hieronymusii was originally described from lakes in the temperate zone (north of Germany), and it probably does not occur in tropical regions. Desikachary (1959) cites two papers from India, both concerning the same locality of " $L$. hieronymusii" (Allahabad), but their very different ecology (rice fields and ponds) indicates at least a separate ecotype. Our Brazilian populations correspond with another tropical taxon, f. robusta, described by Parakutty (1940), also from India (Travancore). They differ from the European specimens (and also from the strains obtained from Lake Dalai, Inner Mongolia, China; Suda et al. 1998), by their morphology (size) and ecology; they represent probably a separate tropical morphotype. Because the f. robusta is phenotypically mostly similar to our Brazilian populations, we consider this taxon as a special tropical planktic Lyngbya-species with aerotopes within cells. The var. crassivaginata Ghose (1927), also described from India, is evidently another type (see dimensions, length of cells). Comparison of all mentioned related species are in table 1 . The Brazilian populations were collected in large reservoirs (in the State of São Paulo), Broa, 


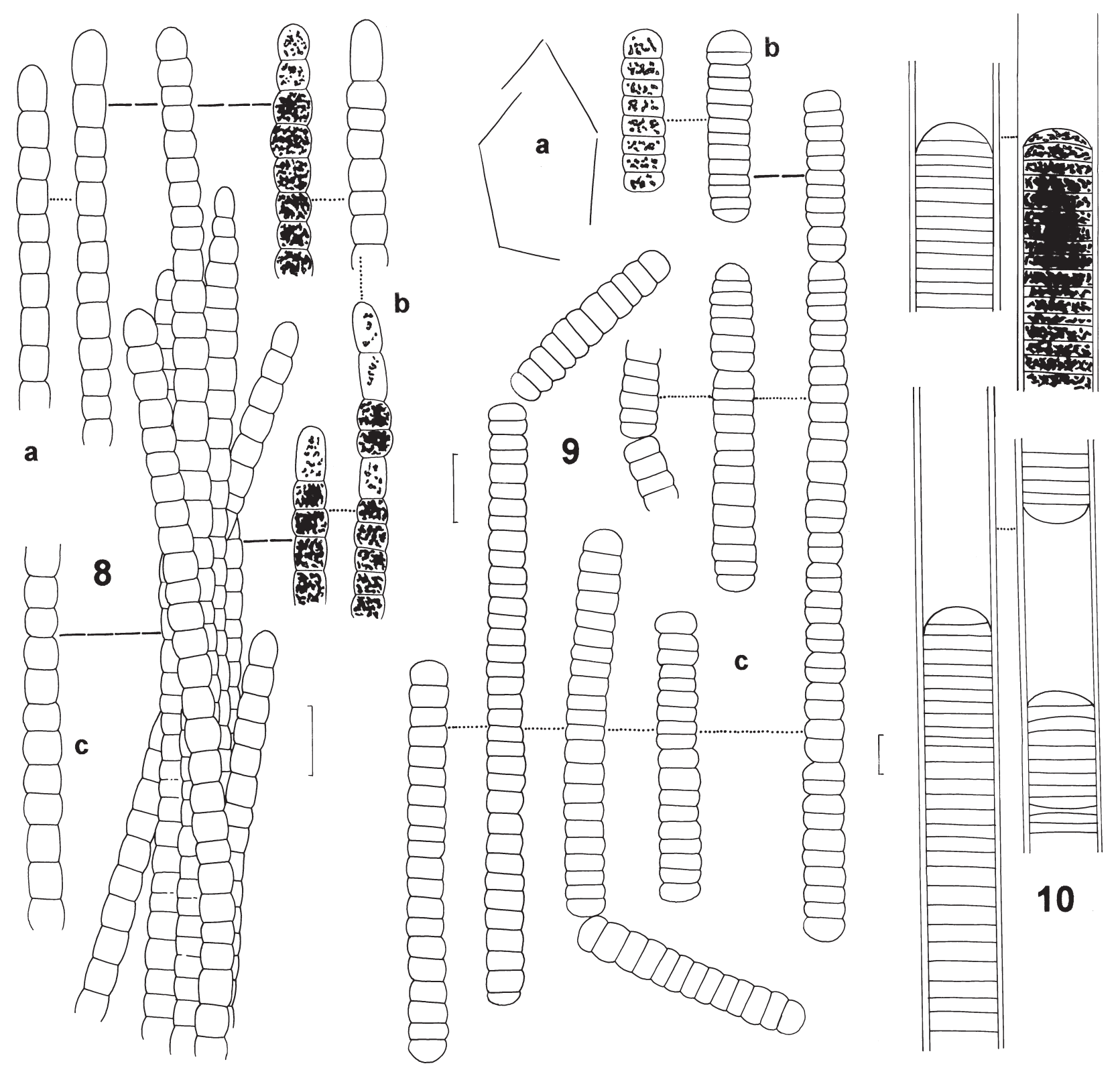

Figure 8. Trichodesmium lacustre: a-b. Details of trichome ends; c. Part of a trichome; d. apical part of a fascicles of trichomes. Figure 9. Hormoscilla fragmentosa: a. Form of trichomes; b. Hormogonia; c. Variability of trichomes. Figure 10. Lyngbya robusta details of filaments. All figures original; all bars $=10 \mu \mathrm{m}$. 
Table 1. Comparison of phenotypic characters of Lyngbya hieronymusii-like taxa.

\begin{tabular}{|c|c|c|c|c|c|}
\hline $\begin{array}{l}\text { Lyngbya } \\
\text { (planktic) }\end{array}$ & $\begin{array}{l}\text { Width of } \\
\text { filaments } \\
\quad(\mu \mathrm{m})\end{array}$ & Sheaths & $\begin{array}{l}\text { Width of } \\
\text { trichomes } \\
\quad(\mu \mathrm{m})\end{array}$ & $\begin{array}{l}\text { Cell length } \\
(\mu \mathrm{m})\end{array}$ & $\begin{array}{l}\text { Constrictions } \\
\text { at cross-walls }\end{array}$ \\
\hline hieronymusii Lemm.1905 (orig. description) & $12-14$ & fine, homogeneous & $11-13$ & $2.5-4$ & - \\
\hline $\begin{array}{l}\text { hieronymusii var. hieronymusii (after } \\
\text { Suda et al.1998) }\end{array}$ & - & firm, thin, colourless & $12.6-14$ & $1.7-2.6$ & - \\
\hline $\begin{array}{l}\text { hieronymusii f. robusta } \\
\text { Parakutty } 1940\end{array}$ & $26.4-33^{*}$ & - & $15-17 *$ & $3-3.5$ & - \\
\hline $\begin{array}{l}\text { Brazilian populations } \\
\quad=L \text {. robusta }\end{array}$ & $17-28 *$ & thick, colourless & $14.5-19(21)^{*}$ & $2.6-5.1$ & - \\
\hline $\begin{array}{l}\text { hieronymusii var. crassivaginata } \\
\text { Ghose } 1927\end{array}$ & $15-20$ & thick, hyaline & $11-14$ & up to $10^{*}$ & - \\
\hline
\end{tabular}

* Dimensions, distinctly separating L. robusta from the typical L. hieronymusii.

Guarapiranga, and particularly in the Cantareira system (complex of reservoirs). However, it is possible, that in the temperate zone of South America also populations corresponding with typical Lyngbya hieronymusii, can occur.

The recognition of the specific tropical cyanobacterial populations is possible only according to precise descriptions of their phenotypic variability and ecological demands of natural populations, combined with the study of their genetic background. This latter methodological approach needs the isolation and purification of strains, or the careful analyses of the cyanobacterial assemblages from natural habitats with the simultaneous analysis of phenotypic diversity. The phenotypic characterization of populations from natural habitats in various geographic regions is the first necessary step for this investigation. Our present study contains descriptions of some probably neglected planktic cyanobacterial types, which seem to be characteristic of freshwater aquatic habitats in Brazil (and Peru, respectively), and which were not yet registered in the up to date reviews of cyanobacterial microflora of South America.

\section{Acknowledgment}

The authors thank particularly Drs. Célia Leite Sant'Anna and Maria Teresa de Paiva Azevedo from the Botanical Institute in São Paulo (SP) and deceased Prof. Dr. Pedro A.C. Senna from the University in
São Carlos (SP) for the invitation to participate in the study of Brazilian cyanobacterial microflora and for very comfortable collaboration. The paper was supported by the Brazilian projects CNPq (Proc. 300316/81) and FAPESP (Proc. 97/05488-7), and the Czech Grant Agency of the Academy of Sciences no. A6005704 and SK6005114.

\section{References}

Anagnostidis, K. \& Komárek, J. 1988. Modern approach to the classification system of cyanophytes. 3 Oscillatoriales. Algological Studies 50-53: 327-472.

Azevedo, M.T.P., Sant'Anna, C.L., Senna, P.A.C., Komárek, J. \& Komárková, J. 2003. Contribution to the microflora of chroococcalean cyanoprokaryotes in São Paulo State, Southeast Brazil. Hoehnea 30: 285-295.

Desikachary, T.V. 1959. Cyanophyta. Indian Council of Agricultural Research, Monographs on Algae. New Delhi.

Ghose, S.L. 1927. The Myxophyceae of Rangoon II. Journal of the Burma Research Society 15: 244-253.

Hoffmann, L. 2005. Nomenclature of Cyanophyta/ Cyanobacteria: roundtable on the unification of the nomenclature under the Botanical and Bacteriological Codes. Algological Studies 117: 13-29.

Komárek, J. 2001. Review of the cyanoprokaryotic genus Romeria. Czech Phycology 1: 5-19.

Komárek, J. \& Azevedo, M.T.P. 2000. Geitlerinema unigranulatum, a common tropical cyanoprokaryote from freshwater reservoirs in Brazil. Algological Studies 99: 39-52.

Lemmermann, E. 1905. Beiträge zur Kenntnis der Planktonalgen XX. Forschungsberichte der Biologischen Station in Plön 12: 154-168. 
Parakutty, P.S. 1940. The Myxophyceae of the Travancore State, India. Proceedings of the Indian Academy of Sciences B, 11: 117-124.

Sant'Anna, C.L., Azevedo, M.T.P., Senna, P.A.C., Komárek, J. \& Komárková, J. 2004. Planktic Cyanobacteria from São Paulo State, Brazil: Chroococcales. Revista Brasileira de Botânica 27: 213-227.

Senna, P.A.C., Peres, A.C. \& Komárek, J. 1998. Coelomoron tropicalis, a new cyanoprocaryotic species from São Paulo State, Brazil. Nova Hedwigia 67: 93-100.
Suda, S., Liu, Y., He, J., Hu, Z., Hirooki, M. \& Watanabe M.M. 1998. Morphological, biochemical and physiological characteristics of Lyngbya hieronymusii var. hieronymusii (Oscillatoriales, Cyanobacteria). Phycological Research 46: 51-55.

Suda, S., Watanabe, M.M., Otsuka, S., Mahakahant, A., Yongmanitchai, W., Nopartnaraporn, N., Liu, Y. \& Day, J.G. 2002. Taxonomic revision of water-bloom-forming species of oscillatorioid cyanobacteria. International Journal of Systematic and Evolutionary Microbiology 52: $1577-1595$. 